\title{
PENGARUH PEMBERIAN "KOMBUCHA" TEH ROSELLA TERHADAP PROFIL DARAH MENCIT (Mus musculus L)
}

\author{
The Effect of "Kombucha" Rosella Tea on the Blood Profile of Mice (Mus musculus L) \\ Mukhani Dwi Hidayanti, Sussi Astuti, Maria Erna Kustyawati \\ Jurusan Teknologi Hasil Pertanian Fakultas Pertanian, Universitas Lampung, \\ Jl. Sumantri Brojonegoro No. 1 Bandar Lampung 35145 \\ Email: sussi_astuti@yahoo.com
}

\begin{abstract}
ABSTRAK
"Kombucha" teh rosella merupakan produk minuman fungsional hasil fermentasi larutan teh dari kelopak bunga rosella dan gula menggunakan starter mikroba "Kombucha" (Acetobacter xylinum dan beberapa jenis khamir). Tujuan penelitian adalah untuk mengetahui pengaruh pemberian "Kombucha" teh rosella terhadap profil darah mencit (Mus musculus L). Penelitian disusun dalam Rancangan Acak Lengkap (RAL) dengan 4 perlakuan dosis "Kombucha" teh rosella yaitu $0,73 \mathrm{ml} / 20 \mathrm{~g} \mathrm{BB}$ mencit (aquadest) $(\mathrm{K}), 0,36 \mathrm{ml} / 20 \mathrm{~g} \mathrm{BB}\left(\mathrm{P}_{1}\right), 0,55 \mathrm{ml} / 20 \mathrm{~g} \mathrm{BB}\left(\mathrm{P}_{2}\right), \mathrm{dan} 0,73 \mathrm{ml} / 20 \mathrm{~g}$ BB $\left(\mathrm{P}_{3}\right)$. Setiap perlakuan terdiri dari 6 ulangan dengan lama perlakuan 30 hari secara oral."Kombucha" teh rosella dibuat dari 5 g kelopak rosella dengan konsentrasi gula sebanyak $250 \mathrm{~g}$ dalam $1000 \mathrm{ml}$ air, diinokulasi dengan kultur "Kombucha" induk dan lama fermentasi 6 hari. Hasil penelitian menunjukkan bahwa pemberian "Kombucha" teh rosella pada ketiga dosis menghasilkan jumlah eritrosit, leukosit dan kadar hemoglobin mencit pada kisaran normal. Tidak terlihat perbedaan diferensiasi butir darah putih (monosit, limfosit, dan neutrofil) mencit akibat perlakuan "Kombucha" teh rosella pada ketiga dosis dengan kontrol. Terlihat adanya kecenderungan peningkatan jumlah eritrosit dan hemoglobin, serta penurunan jumlah leukosit mencit akibat perlakuan "Kombucha" teh rosella pada ketiga dosis dibanding kontrol.
\end{abstract}

Kata kunci: "Kombucha", rosella, teh fermentasi, profil darah, mencit

\begin{abstract}
"Kombucha" rosella tea is a functional fermented beverage product solution from the petals of rosella tea and sugar using a microbial starter "Kombucha" (Acetobacter xylinum and several kind of yeast). The objective of the experiment was to determine the effect of "Kombucha" rosella tea on the blood profile of mice (Mus musculus L). The experiment compiled in a completely randomized design with 4 treatments dose "Kombucha" rosella tea was $0,73 \mathrm{ml} / 20 \mathrm{~g} \mathrm{BB}$ mice (distilled water) $(\mathrm{K}), 0,36 \mathrm{ml} / 20 \mathrm{~g} \mathrm{BB}\left(\mathrm{P}_{1}\right), 0,55 \mathrm{ml} / 20 \mathrm{~g} \mathrm{BB}\left(\mathrm{P}_{2}\right)$, and 0,73 ml/20 $\mathrm{g} \mathrm{BB}\left(\mathrm{P}_{3}\right)$ Each treatment consisted of 6 replicates with given orally for 30 days. "Kombucha" rosella tea was made from 5 g rosella petals with sugar concentration of $250 \mathrm{~g}$ in $1000 \mathrm{ml}$ of water, inoculated with a culture of "Kombucha" and fermentation time 6 days. The results showed that the administration of "Kombucha" rosella tea on the third dose resulted in the number of erythrocytes, leukocytes and hemoglobin levels in the range of normal mice. No visible difference in grain differentiation of white blood (monocytes, lymphocytes, and neutrophils) mice due to treatment "Kombucha" rosella tea on the third dose of the control. Seen a trend increase in the number of erythrocytes and hemoglobin, as well as a decrease in the number of leukocytes mice due to treatment "Kombucha" rosella tea on the third dose compared to controls.
\end{abstract}

Keywords: "Kombucha", rosella, fermented tea, blood profile, mice 


\section{PENDAHULUAN}

Konsumsi bahan makanan yang mengandung antioksidan alami makin populer seiring dengan makin tingginya kepedulian masyarakat untuk menjaga kesehatan. Salah satunya adalah dengan mengkonsumsi cairan hasil fermentasi atau hasil peragian larutan teh, gula, dan jamur kombu yang lazim disebut teh "Kombucha" (Naland, 2004). Teh "Kombucha" merupakan salah satu minuman fungsional yang cukup dikenal oleh masyarakat dan memberikan keuntungan terhadap kesehatan. Teh "Kombucha" berperan dalam mengurangi oksidasi LDL secara in vitro dan kadar kolesterol serum (Tzu dkk., 2007), mempunyai efek hipokolesterolemik (Chen dkk., 2003), mempunyai efek hepatoprotektif (Murugesan dkk., 2009), membantu proses pencernaan, menstabilkan kadar glukosa darah, membantu sistem imun, membuang racun dalam tubuh, dan bermanfaat sebagai antioksidan (Dufresne dan Farnworth, 2000).

Pada umumnya "Kombucha" dibuat dari larutan teh hitam atau teh hijau. Tetapi telah ditemukan jenis minuman teh yang terbuat dari kelopak bunga rosella. Menurut Morton (1999), kandungan gizi kelopak bunga rosella setiap $100 \mathrm{~g}$ sebagai berikut: protein $1,145 \mathrm{~g}$, lemak $2,61 \mathrm{~g}$, serat $12 \mathrm{~g}$, kalsium $1.263 \mathrm{~g}$, fosfor $273,2 \mathrm{mg}$, zat besi $8,98 \mathrm{mg}$, karoten $0,029 \mathrm{mg}$, tiamin $0,117 \mathrm{mg}$, riboflavin $0,227 \mathrm{mg}$, niasin $3,765 \mathrm{mg}$, dan vitamin C $244,4 \mathrm{mg}$. Bunga rosella juga kaya serat yang bermanfaat untuk kesehatan saluran pencernaan. Adenipekun (1998) menyatakan bahwa kadar antosianin kelopak bunga rosella kering sebesar $1,50 \mathrm{~g} / 100 \mathrm{~g}$, sedangkan aktivitas antioksidan kelopak bunga rosella sebesar 63,93\% (Sundah, 2008). Morton (1999) melaporkan bahwa kandungan vitamin C kelopak bunga rosella sebesar $244,4 \mathrm{mg} / 100 \mathrm{~g}$. Selain berfungsi sebagai antioksidan, vitamin $\mathrm{C}$ berfungsi menjaga dan memelihara kesehatan pembuluh-pembuluh kapiler, kesehatan gigi dan gusi, membantu penyerapan zat besi, dan membantu penyembuhan luka.

"Kombucha" teh rosella merupakan salah satu minuman fungsional yang bermanfaat bagi kesehatan, dibuat dari kelopak bunga rosella dan gula (sukrosa) menggunakan starter mikroba "Kombucha" (Acetobacter xylinum dan beberapa jenis khamir). Produk olahan "Kombucha" teh rosella mampu mempertahankan dan mengoptimalkan senyawa antosianin yang terkandung pada rosella karena "Kombucha" merupakan produk fermentasi yang menghasilkan asam. Kondisi asam bersifat menstabilkan antosianin karena antosianin lebih stabil pada lingkungan dengan $\mathrm{pH}$ rendah (Damodaran dkk., 2008). Sukrosa akan dihidrolisis menjadi glukosa dan fruktosa, melalui glikolisis akan dihasilkan etanol dan gliserol. Sebagian glukosa akan digunakan oleh Acetobacter xylinum untuk memproduksi asam organik seperti asam glukonat melalui jalur pentosa fosfat dan biosintesis selulosa (Ross dkk., 1991). Asam glukoronat dalam "Kombucha" dilaporkan memiliki potensi sebagai agen detoksifikasi (Cvetkovic dan Markov, 2002; Jayabalan dkk., 2007; Gharib, 2009). Menurut Blanc (1996), asam asetat, etanol dan asam glukonat merupakan komponen utama dalam cairan "Kombucha"teh. Chen dan Liu (2000) menyatakan bahwa dalam "Kombucha" teh, asam asetat menghasilkan flavor asam dan astringent, sedangkan asam glukonat menghasilkan flavor mild. Dilaporkan lebih lanjut bahwa "Kombucha" teh dengan lama fermentasi 6 sampai 10 hari menghasilkan flavor menyerupai buah segar, sedangkan pada proses fermentasi yang lebih lama mengakibatkan flavor yang menyerupai cuka.

Sejauh ini belum pernah dilaporkan pengaruh pemberian kombucha teh rosella terhadap profil darah dalam kondisi fisiologis tubuh normal. Oleh karena itu, untuk lebih menggali potensi "Kombucha" teh rosella sebagai minuman fungsional, dilakukan penelitian pengaruh pemberian "Kombucha" teh rosella terhadap profil darah dengan menggunakan mencit sebagai hewan model.

\section{METODE PENELITIAN}

Penelitian disusun dalam Rancangan Acak Lengkap (RAL) dengan perlakuan 4 dosis "Kombucha" teh rosella. Setiap perlakuan terdiri dari 6 ulangan (6 ekor mencit). Dosis perlakuan yang diberikan pada mencit adalah (1) 0,73 $\mathrm{ml} / 20 \mathrm{gBB}$ (aquadest) (Kontrol/K), (2) "Kombucha" teh rosella $0,36 \mathrm{ml} / 20 \mathrm{~g} \mathrm{BB}\left(\mathrm{P}_{1}\right)$, (3) "Kombucha" teh rosella 0,55 $\mathrm{ml} / 20 \mathrm{~g} \mathrm{BB}\left(\mathrm{P}_{2}\right)$, dan (4) "Kombucha" teh rosella 0,73 $\mathrm{ml} / 20$ $\mathrm{g} \mathrm{BB}\left(\mathrm{P}_{3}\right)$.

\section{Alat dan Bahan}

Alat-alat yang digunakan adalah panci stainless steel, toples, karet pengikat, kain kassa, penyaring, timbangan dua digit merek Mettler PJ 3000, pH meter merek Lovibond, serta alat gelas untuk analisis kimia. Uji in vivo menggunakan spuit volume $1 \mathrm{ml}$, seperangkat kandang percobaan, tabung venoject, cutter, tissue, kertas label, pipet eritrosit, kamar hitung Improved Neubeuer, mikroskop, Spektrofotometer Varta-307, dan pipet leukosit.

Bahan-bahan yang digunakan untuk pembuatan "Kombucha" adalah rosella, gula pasir, dan kultur "Kombucha". Bahan-bahan yang digunakan untuk analisis adalah larutan $\mathrm{NaOH} 0,1 \mathrm{~N}$, indikator fenolftalein, EDTA, larutan turk, larutan hayem, alkohol 70\%, hemoglobin C, dan aquadest.

\section{Pembuatan "Kombucha" Teh Rosella}

Pembuatan "Kombucha"sebagai berikut: 5 g kelopak rosella dimasukkan dalam $1000 \mathrm{ml}$ air mendidih (panci 
stainless steel), diseduh selama 10 menit, kemudian dilakukan penyaringan untuk memisahkan ampas kelopak rosella. Terhadap larutan teh yang diperoleh ditambah gula pasir sebanyak $25 \%$ dari volume seduhan yaitu $250 \mathrm{~g}$, diaduk hingga larut dan dibiarkan hingga mencapai suhu ruang, kemudian dipindahkan ke dalam toples. Setelah larutan teh mencapai suhu ruang, larutan teh diinokulasi dengan kultur "Kombucha" induk, ditutup kain kasa dan diikat karet. Fermentasi dilakukan pada suhu ruang selama 6 hari sehingga diperoleh "Kombucha" teh rosella sebagai bahan baku utama uji in vivo.

\section{Pengujian In Vivo}

Pengujian in vivo menggunakan 24 ekor mencit (Mus musculus L) jantan strain BALB/C umur 2 - 3 bulan dengan berat $20 \mathrm{~g}$ - $30 \mathrm{~g}$ yang diperoleh dari BPPV (Balai Penyidikan dan Pengujian Veteriner) Regional III Bandar Lampung. Keempat kelompok mencit perlakuan mendapat pakan berupa pellet yang diperoleh dari CV. Sanusi Taufik Bandar Lampung sebanyak $15 \mathrm{~g} /$ ekor/hari dan air minum dalam kemasan digunakan sebagai air minum. Adaptasi mencit dilakukan selama 7 hari, selanjutnya mencit ditimbang dan dibagi dalam 4 kelompok. Masing-masing kelompok terdiri dari 6 ekor mencit, di mana perbedaan berat badan antar mencit dalam satu kelompok tidak lebih dari $10 \mathrm{~g}$, dan perbedaan berat badan mencit antar kelompok tidak lebih dari $5 \mathrm{~g}$.

Menurut Naland (2004), dosis pemberian "Kombucha" untuk dewasa atau 18 tahun ke atas dengan berat badan $50 \mathrm{~kg}$ adalah satu gelas $(200 \mathrm{ml})$. Mengacu pada pernyataan Naland (2004), pemberian "Kombucha" teh rosella ditetapkan pada empat tingkatan dosis yaitu (1) kontrol (aquadest $200 \mathrm{ml} / 50$ $\mathrm{kg} \mathrm{BB}$ ), (2) "Kombucha" teh rosella $100 \mathrm{ml} / 50 \mathrm{~kg} \mathrm{BB}$, (3) "Kombucha" teh rosella $150 \mathrm{ml} / 50 \mathrm{~kg} \mathrm{BB}$, (4) "Kombucha" teh rosella $200 \mathrm{ml} / 50 \mathrm{~kg} \mathrm{BB}$. Konversi berat badan mencit $20 \mathrm{~g}$ dengan berat badan manusia $70 \mathrm{~kg}$ adalah 0,0026 (Laurence dan Bacharah, 1964). Berdasarkan hasil perhitungan, empat dosis "Kombucha" teh rosella yang diberikan pada mencit adalah: (1) kontrol (aquadest 0,73 ml/20 g BB) (K), (2) "Kombucha" teh rosella $0,36 \mathrm{ml} / 20 \mathrm{~g} \mathrm{BB}\left(\mathrm{P}_{1}\right),(3)$ "Kombucha" teh rosella $0,55 \mathrm{ml} / 20 \mathrm{~g} \mathrm{BB}\left(\mathrm{P}_{2}\right)$, dan (4) "Kombucha" teh rosella 0,73 $\mathrm{ml} / 20 \mathrm{~g} \mathrm{BB}\left(\mathrm{P}_{3}\right)$. "Kombucha" teh rosella diberikan secara oral sesuai dengan dosis perlakuan menggunakan spuit volume $1 \mathrm{ml}$ yang ujungnya ditumpulkan sebanyak satu kali per hari (pagi hari). Perlakuan diberikan selama 30 hari. Selama 30 hari perlakuan, mencit diberi pakan pellet dan air minum secara ad libitum. Setelah 30 hari perlakuan, mencit diterminasi dan darah diambil melalui vena ventranalis dengan cara menyembelih bagian leher mencit menggunakan cutter. Darah ditampung dalam tabung venoject BD Vacutainer K2 EDTA 5,4 mg, selanjutnya dilakukan pengujian terhadap parameter yang diuji.

\section{Pengamatan}

Parameter yang diamati adalah jumlah sel darah merah (eritrosit) (Sabrina, 2005), jumlah sel darah putih (leukosit) (Sabrina, 2005), diferensiasi sel darah putih (Renova, 2005), dan kadar hemoglobin (Maysaroh, 2010). Pengamatan derajat keasaman $(\mathrm{pH})$ dilakukan terhadap "Kombucha" teh rosella yang digunakan sebagai bahan baku utama uji in vivo (AOAC, 1990).

\section{Analisis Data}

Data diolah dengan analisis ragam untuk mengetahui adanya pengaruh akibat perlakuan. Untuk mengetahui perbedaan antar perlakuan, dilakukan uji lanjut Beda Nyata Terkecil (BNT) pada taraf $5 \%$.

\section{HASIL DAN PEMBAHASAN}

\section{Jumlah Sel Darah Merah (Eritrosit)}

Hasil analisis ragam menunjukkan bahwa perlakuan pemberian "Kombucha" teh rosella pada berbagai dosis berbeda nyata terhadap jumlah sel darah merah (eritrosit) mencit. Rata-rata jumlah sel darah merah mencit yang diberi "Kombucha" teh rosella dengan berbagai dosis disajikan pada Tabel 1.

Tabel 1. Rata-rata jumlah sel darah merah (eritrosit) mencit yang diberi "Kombucha" teh rosella dengan berbagai dosis

\begin{tabular}{lc}
\hline Perlakuan & Jumlah sel darah merah $\left(\mathrm{juta} / \mathrm{mm}^{3}\right)$ \\
\hline $\mathrm{K}$ & $4,57 \pm 0,16^{\mathrm{b}}$ \\
$\mathrm{P}_{1}$ & $4,78 \pm 0,24^{\mathrm{b}}$ \\
$\mathrm{P}_{2}$ & $5,00 \pm 0,56^{\mathrm{b}}$ \\
$\mathrm{P}_{3}$ & $5,77 \pm 0,36^{\mathrm{a}}$ \\
\hline
\end{tabular}

Keterangan : Angka $(\mu \pm$ sd) yang diikuti huruf yang sama berarti tidak berbeda nyata pada taraf $5 \%$ BNT $(0,05)=0,43$

Secara umum, terlihat bahwa jumlah eritrosit mencit yang mendapat perlakuan "Kombucha" teh rosella lebih tinggi dibanding perlakuan kontrol $(\mathrm{K})$ yang tidak mendapat perlakuan kombucha. Namun, hasil uji lanjut dengan BNT menunjukkan bahwa perlakuan $\mathrm{K}$ tidak berbeda nyata dengan perlakuan $\mathrm{P}_{1}$ dan $\mathrm{P}_{2}$, sedangkan perlakuan $\mathrm{P}_{3}$ dengan dosis "Kombucha" teh rosella tertinggi berbeda dengan perlakuan $\mathrm{K}, \mathrm{P}_{1}$, dan $\mathrm{P}_{2}$.

Pemberian "Kombucha" teh rosella pada dosis yang paling tinggi $(0,73 \mathrm{ml} / 20 \mathrm{~g} \mathrm{BB})$ secara signifikan berperan dalam meningkatkan jumlah sel darah merah mencit dibanding pemberian "Kombucha" teh rosella pada dosis 
yang lebih rendah $(0,36 \mathrm{ml} / 20 \mathrm{~g}$ BB dan $0,55 \mathrm{ml} / 20 \mathrm{~g} \mathrm{BB})$. Menurut Arrington (1972), jumlah rata-rata sel darah merah mencit normal berkisar antara 4-6 juta/ $\mathrm{mm}^{3}$. Hasil penelitian menunjukkan bahwa jumlah rata-rata sel darah merah mencit akibat pemberian "Kombucha" teh rosella berada pada kisaran normal.

Kecenderungan peningkatan jumlah sel darah merah mencit perlakuan akibat pemberian kombucha teh rosella diduga dipengaruhi oleh senyawa antosianin yang berperan sebagai antioksidan dalam "Kombucha" teh rosella. Adenipekun (1998) menyatakan bahwa kadar antosianin kelopak bunga rosella kering sebesar 1,50 g/100 g. Menurut Sundah (2008), aktivitas antioksidan kelopak bunga rosella sebesar 63,93\%. Chu dan Chen (2006) melaporkan bahwa kombucha mengalami peningkatan aktivitas antioksidan sebesar $17 \%$ selama proses fermentasi melalui pengukuran menggunakan DPPH. Senyawa antosianin diduga dapat menstimulir produksi eritropoietin sehingga mempengaruhi pembentukan sel darah merah.

Guyton dan Hall (1997) menyebutkan bahwa fungsi eritropoietin dalam pembentukan sel darah merah adalah merangsang produksi proeritoblast dari sel-sel stem hemopoietik dalam sumsum tulang. Eritropoietin juga berfungsi mempercepat tahapan eritroblastik dibanding keadaan normal, dan selanjutnya akan melampaui batas kecepatan pembentukan sel baru sampai jumlah sel darah merah yang terbentuk mencukupi untuk mengangkut oksigen ke jaringan. Eritrosit diproduksi di sumsum tulang belakang dan berfungsi membawa oksigen ke seluruh tubuh. Lama masa hidup eritrosit yang tetap menyebabkan jumlah eritrosit relatif tetap untuk dihancurkan setiap hari oleh Reticulo Endoplasmic System (RES) (Kresno, 1988).

Sumsum tulang belakang membutuhkan bahan baku yang cukup untuk memproduksi sel darah merah, antara lain zat besi $(\mathrm{Fe})$, asam amino, vitamin $\mathrm{B} 12$, asam folat, vitamin B2, vitamin B6, vitamin C, vitamin E, mineral (kobalt dan tembaga) serta hormon eritropoeitin (Swenson, 1997). Menurut Morton (1999), setiap $100 \mathrm{~g}$ kelopak bunga rosella mengandung protein $1,145 \mathrm{~g}$, zat besi $8,98 \mathrm{mg}$, dan vitamin C $244,4 \mathrm{mg}$. Zat besi dan vitamin C yang terkandung dalam rosella diduga berpengaruh terhadap produksi eritrosit dalam sumsum tulang belakang sehingga pembentukan eritrosit dapat terus berlangsung dan tidak mengalami hambatan. Guyton (1995) menyebutkan bahwa kecepatan pembentukan eritrosit dikontrol oleh hormon eritropoietin. Peningkatan produksi eritropoietin akan merangsang eritropoiesis dengan jalan meningkatkan sintesis hemoglobin, mengurangi waktu pematangan eritrosit dan melepaskan retikulosit ke dalam sirkulasi pada stadium lebih awal (Hoffbrand dkk., 2005).

\section{Jumlah Sel Darah Putih (Leukosit)}

Hasil analisis ragam menunjukkan bahwa perlakuan pemberian "Kombucha" teh rosella pada berbagai dosis berbeda nyata terhadap jumlah sel darah putih (leukosit) mencit. Rata-rata jumlah sel darah putih (leukosit) mencit yang diberi perlakuan "Kombucha" teh rosella dengan berbagai dosis disajikan pada Tabel 2 .

Tabel 2. Rata-rata jumlah sel darah putih (leukosit) mencit yang diberi perlakuan "Kombucha" teh rosella dengan berbagai dosis

\begin{tabular}{lc}
\hline Perlakuan & Jumlah sel darah putih $\left(\mathrm{ribu} / \mathrm{mm}^{3}\right)$ \\
\hline $\mathrm{K}$ & $12,62 \pm 0,81^{\mathrm{ab}}$ \\
$\mathrm{P}_{1}$ & $13,38 \pm 1,40^{\mathrm{a}}$ \\
$\mathrm{P}_{2}$ & $11,75 \pm 1,55^{\mathrm{b}}$ \\
$\mathrm{P}_{3}$ & $9,73 \pm 1,25^{\mathrm{c}}$ \\
\hline Keterangan : Angka $(\mu \pm$ sd) yang diikuti huruf yang sama berarti tidak \\
\multicolumn{2}{c}{ berbeda nyata pada taraf $5 \%$} \\
BNT $(0,05)=0,434$
\end{tabular}

Sel darah putih merupakan sistem pertahanan terhadap benda-benda asing yang dapat menimbulkan peradangan dan infeksi dalam tubuh. Hasil uji lanjut BNT menunjukkan bahwa perlakuan $\mathrm{K}$ tidak berbeda dengan perlakuan $\mathrm{P}_{1}$ dan $\mathrm{P}_{2}$. Namun, terlihat adanya perbedaan jumlah sel darah putih pada ketiga perlakuan $\mathrm{P}_{1}, \mathrm{P}_{2}$, dan $\mathrm{P}_{3}$ yang diberi "Kombucha" teh rosella. Semakin tinggi dosis "Kombucha" teh rosella yang diberikan, jumlah sel darah putih (leukosit) mencit semakin menurun. Perlakuan $P_{1}$ memiliki jumlah rata-rata leukosit tertinggi, artinya perlindungan tubuh mencit terhadap virus ataupun bakteri juga tinggi. Perlakuan $\mathrm{P}_{3}$ yang mendapat "Kombucha" teh rosella dengan dosis paling tinggi memiliki jumlah rata-rata leukosit paling rendah dibanding perlakuan $\mathrm{P}_{1}$ dan $\mathrm{P}_{2}$, artinya perlindungan tubuh mencit terhadap virus dan penyakit pada perlakuan $\mathrm{P}_{3}$ lebih rendah dibandingkan $P_{1}$ dan $P_{2}$. Menurut Arrington (1972), jumlah sel darah putih normal pada mencit berkisar antara 6-12,6 ribu/ $\mathrm{mm}^{3}$. Hasil pengamatan menunjukkan bahwa jumlah sel darah putih mencit perlakuan berada pada kisaran normal, kecuali perlakuan $\mathrm{P}_{1}$ yang mendapat "Kombucha" teh rosella pada dosis paling rendah memiliki jumlah sel darah putih melebihi normal, yaitu $13,38 \mathrm{ribu} / \mathrm{mm}^{3}$.

Leukosit terdiri atas granulosit atau sel polimorfonuklear yang jumlahnya paling banyak yaitu sekitar $75 \%$ dari seluruh sel darah putih, neutrofil, eosinofil, basofil, limfosit, dan monosit yang mempunyai sifat fagosit (Swenson, 1997). Penurunan jumlah leukosit akibat pemberian "Kombucha" teh rosella pada dosis yang lebih tinggi disebabkan leukosit tidak diproduksi dalam tubuh akibat adanya kandungan antosianin dan vitamin $\mathrm{C}$ yang berperan sebagai antioksidan 
pada "Kombucha" teh rosella. Hal ini mengakibatkan tingginya pertahanan tubuh mencit terhadap benda asing yang masuk ke dalam tubuh yang dapat merusak jaringan. Peran antosianin dan vitamin $\mathrm{C}$ sebagai antioksidan adalah dengan cara mengikat radikal bebas dan molekul yang bersifat sangat reaktif. Tingginya konsumsi antioksidan dapat meningkatkan sistem imunitas tubuh terhadap benda asing atau antigen. Xu dkk. (2011) melaporkan bahwa kemampuan teh dalam menghambat produksi Nitrit Oxide (NO) dalam sel mengalami peningkatan ketika teh difermentasi. NO berperan dalam mediasi sitotoksisitas makrofag dan mengatur tekanan darah. Keseimbangan NO menunjukkan pentingnya pengaturan proses fisiologis seperti vasodilatasi dan pertahanan inang. Dalam "Kombucha" teh rosella juga terkandung vitamin B1, B2, B3, dan vitamin C yang dibutuhkan tubuh dan berperan sebagai katalisator. Menurut Lehninger (1990), vitamin berfungsi sebagai prekursor untuk kofaktor enzim yang membantu peran enzim sebagai katalis dalam metabolisme karbohidrat, lemak, dan protein.

\section{Diferensiasi Sel Darah Putih (Leukosit)}

Sel-sel darah putih normal dikelompokkan menjadi granulosit dan agranulosit. Granulosit terdiri dari neutrofil, eosinofil, dan basofil sedangkan agranulosit terdiri dari limfosit dan monosit (Swenson, 1997). Masing-masing komponen atau jenis sel darah putih memiliki berbagai macam fungsi khusus, namun secara garis besar bentuk-bentuk ini berfungsi sebagai sistem pertahanan tubuh terhadap benda asing. Ratarata persentase neutrofil, limfosit, dan monosit disajikan pada Tabel 3.

Tabel 3. Persentase rata-rata jumlah sel diferensiasi butir darah putih (monosit, limfosit, dan neutrofil) mencit yang diberi perlakuan "Kombucha" teh rosella pada berbagai dosis

\begin{tabular}{lccc}
\hline Perlakuan & Monosit (\%) & Neutrofil (\%) & Limfosit (\%) \\
\hline $\mathrm{K}$ & $7,67 \pm 2,58^{\mathrm{a}}$ & $32,33 \pm 3,20^{\mathrm{a}}$ & $59,83 \pm 3,19^{\mathrm{a}}$ \\
$\mathrm{P}_{1}$ & $11,83 \pm 3,49^{\mathrm{a}}$ & $29,33 \pm 3,67^{\mathrm{a}}$ & $58,83 \pm 5,81^{\mathrm{a}}$ \\
$\mathrm{P}_{2}$ & $9,50 \pm 5,82^{\mathrm{a}}$ & $31,33 \pm 7,74^{\mathrm{a}}$ & $59,17 \pm 11,32^{\mathrm{a}}$ \\
$\mathrm{P}_{3}$ & $6,33 \pm 2,25^{\mathrm{a}}$ & $32,00 \pm 4,52^{\mathrm{a}}$ & $61,67 \pm 3,83^{\mathrm{a}}$ \\
\hline
\end{tabular}

Keterangan: Angka yang diikuti huruf yang sama berarti tidak berbeda nyata pada taraf $5 \%$ BNT $(0,05)=0,43$

\section{Monosit}

Perlakuan pemberian "Kombucha" teh rosella tidak berbeda nyata terhadap jumlah sel monosit mencit. Menurut Arrington (1972), jumlah monosit pada mencit normal berkisar antara 1-12\%. Hasil pengamatan menunjukkan bahwa jumlah monosit mencit akibat pemberian "Kombucha" teh rosella berada pada kisaran normal.
Monosit merupakan sel darah putih yang menyerupai heterofil, bersifat fagositik yaitu memiliki kemampuan untuk menelan benda asing seperti bakteri. Monosit merupakan fagosit aktif serta mengandung peroksidase dan enzim lisosom. Monosit dimobilisasi bersama dengan heterofil sebagai bagian respon peradangan dan membentuk garis pertahanan kedua terhadap bakteri. Monosit memasuki sirkulasi dari sumsum tulang belakang, tetapi setelah berkisar 24 jam akan memasuki jaringan untuk menjadi makrofag jaringan (Ganong, 2003). Sel ini memiliki granula lisosom yang lebih kecil dan lebih sedikit jumlahnya dibandingkan sel neutrofil, serta mampu menghancurkan bahan-bahan patogen yang tidak dapat dikontrol oleh neutrofil (Jain, 1993). Monosit dalam jaringan akan berubah menjadi makrofag yang dapat memfagositosis benda-benda asing yang masuk ke dalam tubuh. Terjadinya kecenderungan penurunan jumlah sel monosit pada kelompok yang diberi "Kombucha" teh rosella pada dosis yang semakin tinggi diduga karena pada kelompok tersebut tidak terjadi peningkatan aktivitas fagositosis terhadap benda asing atau kemampuan fagositosis berjalan lambat.

\section{Neutrofil}

Perlakuan secara oral "Kombucha" teh rosella tidak berbeda nyata terhadap jumlah sel neutrofil mencit. Namun terlihat adanya kecenderungan peningkatan jumlah sel neutrofil pada kelompok yang diberi "Kombucha" teh rosella dengan dosis yang semakin tinggi.

Sel neutrofil berdiameter 10-12 $\mu \mathrm{m}$ dan memiliki butirbutir halus (granula) dalam sitoplasma serta inti bergelambir. Banyaknya gelambir pada inti sel ini tergantung pada lamanya sel neutrofil beredar di dalam sirkulasi darah (Jain, 1993). Jumlah neutrofil pada mencit normal berkisar antara 12-30 \% (Arrington, 1972). Peningkatan jumlah rata-rata sel neutrofil mencit karena sel neutrofil merupakan garis pertahanan seluler pertama dalam proses peradangan dan perlukaan, serta berperan penting dalam proses fagositosis dan membunuh mikroorganisme. Sel neutrofil juga berperan dalam proses peradangan akut pada tubuh (Jain, 1993). Menurut Martini dkk. (1992), sebagai sel yang memiliki mobilitas tinggi, neutrofil merupakan sel leukosit pertama yang datang pada lokasi perlukaan. Kemampuan kemotaktik neutrofil dipengaruhi oleh faktor-faktor kemotaksis dalam jaringan yaitu substansi yang dilepaskan dari jaringan rusak akibat perlukaan.

\section{Limfosit}

Perlakuan secara oral "Kombucha" teh rosella tidak berbeda nyata terhadap jumlah sel limfosit mencit. Namun terlihat adanya kecenderungan peningkatan jumlah sel limfosit pada kelompok yang diberi "Kombucha" teh rosella 
dengan dosis yang semakin tinggi. Menurut Arrington (1972), jumlah limfosit pada mencit normal berkisar antara 55-85\%. Hasil pengamatan menunjukkan bahwa jumlah limfosit mencit akibat pemberian "Kombucha" teh rosella berada pada kisaran normal.

Limfosit adalah leukosit agranulosit yang mempunyai ukuran dan bentuk yang bervariasi. Limfosit diproduksi dalam tulang belakang, limfa, saluran limfa, dan timus. Setelah kelahiran, limfosit dibentuk di sumsum tulang belakang, namun sebagian besar dibentuk dari sel prekursor yang berasal dari sumsum tulang di dalam kelenjar limfa, saluran limfa, dan timus. Pada umumnya limfosit memasuki sistem peredaran darah melalui pembuluh limfa. Sel limfosit memiliki kemampuan untuk melakukan resirkulasi di dalam peredaran darah, sehingga jumlah sel limfosit yang masuk dan keluar atau meninggalkan sirkulasi darah relatif konstan (Meyer dkk., 1975). Menurut Jain (1993), sekitar $70 \%$ limfosit darah perifer yang bermigrasi ke dalam jaringan akan kembali ke dalam sirkulasi darah melalui pembuluh limfa.

Kemampuan resirkulasi limfosit sangat penting terutama dalam proses mekanisme distribusi sel-sel limfoid. Hal ini berhubungan dengan respon sistem kekebalan yaitu dengan terakumulasinya sejumlah besar limfosit pada lokasi antigen di dalam jaringan dan dapat berelokasi ke tempat lain di dalam jaringan untuk melakukan respon kekebalan (Jain, 1993). Dalam proses tanggap kebal, limfosit terdiri dari sel-B dan sel-T yang merupakan pengontrol dalam sistem imun. Sel B yang berdiferensiasi menjadi sel plasma akan memproduksi antibodi, sedangkan sel-T dapat melepaskan berbagai bahan yang mempunyai efek biologis yang disebut limfokin. Limfosit T mula-mula bermigrasi ke dan diolah lebih dahulu dalam kelenjar timus, sedangkan limfosit B mula-mula diolah lebih dahulu dalam hati selama masa pertengahan janin, dan dalam sumsum tulang pada masa akhir janin dan sesudah dilahirkan (Guyton dan Hall, 1997). Peranan limfosit sangat penting dalam aktivitas produksi antibodi humoral dan pembentukan pertahanan seluler, serta bertanggung jawab terhadap keragaman antibodi. Keberadaan jaringan rusak dan invasi mikroorganisme di dalam tubuh akan merangsang aktivitas sel makrofag sehingga akan merangsang kerja sel-T dan sel-B. Di dalam tubuh sel-T akan bermigrasi ke dalam jaringan dan langsung menyerang sel-sel asing pada jaringan tersebut sedangkan sel-B akan berdiferensiasi menjadi sel plasma yang mensekresi antibodi dan akan menyerang sel-sel asing sampai pada bagian tubuh yang lokasinya jauh (Jain, 1993). Peningkatan sel limfosit biasanya dapat ditemukan pada kondisi stress, baik emosional maupun fisik, infeksi kronis, dan peradangan kronis. Sedangkan penurunan jumlah limfosit dapat ditemukan pada kejadian infeksi virus (penurunan bersifat sementara dan akan naik lagi jumlahnya) (Meyer dkk., 1975).

\section{Kadar Hemoglobin Darah}

Hasil analisis ragam menunjukkan bahwa perlakuan pemberian "Kombucha" teh rosella pada berbagai dosis berbeda nyata terhadap kadar hemoglobin darah mencit. Ratarata kadar hemoglobin darah mencit yang diberi perlakuan "Kombucha" teh rosella dengan berbagai tingkatan dosis disajikan pada Tabel 4 .

Tabel 4. Rata-rata kadar hemoglobin darah mencit yang diberi "Kombucha" teh rosella dengan berbagai dosis

\begin{tabular}{lc}
\hline Perlakuan & Kadar Hemoglobin $(\mathrm{g} / \mathrm{dL})$ \\
\hline $\mathrm{K}$ & $19,30 \pm 0,38 \mathrm{ab}$ \\
$\mathrm{P}_{1}$ & $18,28 \pm 0,68 \mathrm{~b}$ \\
$\mathrm{P}_{2}$ & $15,32 \pm 1,84 \mathrm{c}$ \\
$\mathrm{P}_{3}$ & $20,13 \pm 1,13 \mathrm{a}$ \\
\hline
\end{tabular}

Keterangan : Angka $(\mu \pm$ sd) yang diikuti huruf yang sama berarti tidak berbeda nyata pada taraf $5 \%$ $\operatorname{BNT}(0,05)=0,43$

Hemoglobin merupakan senyawa organik kompleks yang utama dalam tubuh manusia berupa pigmen merah yang kaya zat besi. Sebanyak 90\% eritrosit vertebrata terdiri atas pigmen merah $\mathrm{Hb}$ (Martini dkk., 1992). Hasil uji lanjut BNT menunjukkan bahwa perlakuan $\mathrm{K}$ tidak berbeda dengan pemberian "Kombucha" teh rosella pada dosis tertinggi $\left(\mathrm{P}_{3}\right)$ dan terendah $\left(\mathrm{P}_{1}\right)$. Namun terlihat perbedaan yang nyata antara perlakuan $\mathrm{P}_{2}$ dengan ketiga perlakuan yang lain. Walaupun perlakuan $\mathrm{P}_{3}$ memperlihatkan kadar hemoglobin tertinggi, namun hasil uji BNT menunjukkan tidak terlihat perbedaan antara $\mathrm{P}_{3}$ dengan kontrol. Menurut Arrington (1972), kadar ratarata hemoglobin darah mencit normal adalah 10-19 g/100 ml.

Tingginya kadar $\mathrm{Hb}$ pada mencit yang diberi "Kombucha" teh rosella dipengaruhi oleh kandungan senyawa aktif "Kombucha" teh rosella yang berhubungan dengan pembentukan sel darah merah (eritrosit). Kepekatan warna merah teh kelopak rosella menunjukkan kadar antosianin yang terkandung di dalamnya. Semakin pekat warna merah, rasa teh rosella akan makin asam dan kadar antosianin makin tinggi. Menurut Eskin (1990), semakin tinggi kandungan antosianin suatu bahan, maka semakin tinggi intensitas warna merah yang dihasilkan. "Kombucha" teh rosella diduga memiliki kandungan antosianin tinggi karena berwarna merah pekat dan memiliki pH yang rendah (asam). Damodaran dkk. (2008) menyatakan bahwa kondisi asam dapat menstabilkan antosianin karena antosianin lebih stabil pada lingkungan dengan $\mathrm{pH}$ rendah, sehingga aktivitas antosianin pada produk "Kombucha" akan lebih optimal. Hasil pengamatan terhadap "Kombucha" teh rosella menunjukkan bahwa nilai $\mathrm{pH}$ "Kombucha" teh rosella sebesar 2,81. Chen dan Liu (2000) melaporkan bahwa nilai $\mathrm{pH}$ kombucha teh setelah fermentasi 
30 hari sekitar 2,5. Menurut Jayabalan dkk. (2007), dalam proses pembuatan kombucha dihasilkan asam-asam organik seperti asam asetat yang berasal dari proses fermentasi Acetobacterxylinum. Selain asam asetat juga terdapat asam glukoronat dan asam glukonat (Chen dan Liu, 2000). Akumulasi asam-asam organik yang dihasilkan berakibat pada penurunan $\mathrm{pH}$. Kandungan vitamin dalam "Kombucha" teh rosella seperti vitamin B1, B2, B3, dan vitamin C diduga mempercepat proses pembentukan $\mathrm{Hb}$ karena vitamin bekerja sebagai katalisator di dalam tubuh.

Peningkatan atau kadar hemoglobin yang tinggi umumnya disebabkan oleh bertambahnya jumlah eritrosit yang diproduksi sumsum tulang. Sumsum tulang membutuhkan bahan baku yang cukup untuk memproduksi sel darah merah, yakni zat besi (Fe), asam amino, vitamin B12, asam folat, B2, B6, vitamin C, vitamin E, mineral (kobalt dan tembaga) serta hormon eritropoeitin (Swenson, 1997). Menurut Guyton (1995), zat besi berperan penting dalam pembentukan hemoglobin, mioglobin, dan substansi lain seperti sitokrom, sitokrom oksidase, peroksidase, dan katalase. Zat besi juga merupakan komponen heme yang sangat penting. Morton (1999) menyatakan bahwa kandungan zat besi dalam kelopak rosella sebesar $8,98 \mathrm{mg} / 100 \mathrm{~g}$ sehingga terjadinya peningkatan kadar hemoglobin mencit diduga karena zat besi yang terkandung dalam kelopak rosella berperan dalam memproduksi jumlah sel darah merah.

Menurut Kresno (1988), zat besi diserap dari saluran pencernaan dalam bentuk garam ferro $\left(\mathrm{Fe}^{2+}\right)$. Sebagian zat besi dilepaskan dalam sirkulasi dan dalam sirkulasi besi diikat oleh transferin yaitu suatu -1-globulin yang berfungsi mengangkut zat besi dan mengantarkannya ke tempat pembentukan $\mathrm{Hb}$ yaitu eritroblast. Dari eritroblast, dilanjutkan sedikit ke dalam stadium retikulosit, jika retikulosit meninggalkan sumsum tulang belakang dan masuk ke dalam aliran darah, retikulosit tetap membentuk $\mathrm{Hb}$ sedikit selama beberapa hari. Bagian heme dari molekul $\mathrm{Hb}$ disintesis terutama dari asam asetat dan gliserin. Kebanyakan sintesis ini terjadi dalam mitokondria. Asam asetat akan mengalami perubahan dalam siklus Krebs menjadi suksinil KoA. Kedua molekul suksinil KoA akan bergabung dengan 2 mol glisin membentuk senyawa pirol, dan sebaliknya empat senyawa tersebut akan saling berkaitan membentuk senyawa protoporfirin. Salah satu protoporfirin yaitu protoporfirin IX akan berkaitan dengan besi pembentuk molekul heme. Akhirnya 4 molekul heme akan berkaitan dengan ikatan polipeptida yang panjang. Ikatan polipeptida disintesis di ribosom. Ikatan antara 4 molekul heme dan polipeptida tersebut akan membentuk suatu sub unit $\mathrm{Hb}$ yang disebut dengan rantai $\mathrm{Hb}$. Keempat rantai $\mathrm{Hb}$ akan bergabung satu sama lain secara longgar membentuk molekul $\mathrm{Hb}$ yang lengkap. Berdasarkan uraian tersebut, zat besi dapat meningkatkan sintesis $\mathrm{Hb}$.

\section{KESIMPULAN}

Pemberian "Kombucha" teh rosella pada ketiga dosis menghasilkan jumlah eritrosit, leukosit dan kadar hemoglobin mencit pada kisaran normal. Tidak terlihat perbedaan diferensiasi butir darah putih (monosit, limfosit, dan neutrofil) mencit akibat perlakuan "Kombucha" teh rosella pada ketiga dosis dengan kontrol. Terlihat adanya kecenderungan peningkatan jumlah eritrosit dan hemoglobin, serta penurunan jumlah leukosit mencit akibat perlakuan "Kombucha" teh rosella pada ketiga dosis dibanding kontrol.

\section{UCAPAN TERIMA KASIH}

Penulis mengucapkan terima kasih kepada Dr. Ir. Suharyono AS, M.S. dan Dr. Ir. Subeki, M.Si. atas saran yang telah diberikan selama pelaksanaan penelitian dan penulisan artikel ini.

\section{DAFTAR PUSTAKA}

Adenipekun, I.T. (1998). Extraction and Colors of Roselle (Hibiscus sabdariffa L.) Juice. University of Ibadan. Ibadan.

AOAC. (1990). Official Methods of Analysis. Fifteenth Edition. Published by the AOAC, Inc., Siute 400, 2200 Wilson Boulevard, Arlington, Virginia 2220, USA.

Arrington, L. R. (1972). Introductory Laboratory Animal Science. The Interstate Printer and Publisher, Inc. Danville. Illinois.

Blanc, P.J. (1996). Characterization of the tea fungus metabolites. Biotechnology Letters 18: 139-142.

Chen, C. dan Liu, B.Y. (2000). Change in major components of tea fungus metabolites during prolonged fermentation. Journal of Apllied Microbiology 89: 834-839.

Chen, C.C., Hsu, J.D., Wang, S.F., Ching, H.C., Yang, M.Y. dan Kao, E.S. (2003). Hibiscus sabdariffa extracts inhibits the development of atherosclerosis in cholesterol-fed rabbits. Journal of Agricultural and Food Chemistry 51(18): 5472-5477.

Chu, S.C. dan Chen, C. (2006). Effects of origins and fermentation time on the antioxidant activities of Kombucha. Food Chemistry 98: 502-507.

Cvetkovic, D.D. dan Markov, S.L. (2002). Cultivation of tea fungus on malt extract medium. Acta Periodica Technologica 33: 117-126.

Damodaran, S., Parkin, K.L. dan Fennema, O.R. (2008). Fennema's Food Chemistry. $4^{\text {rd }}$ Ed. CRC Press Taylor and Francis Group. Boca Raton, London, New York. 
Dufresne, C. dan Farnworth, E. (2000). Tea, kombucha and health: a review. Food Research International 33: 409421.

Eskin, N.A.M. (1990). Plant Pigments, Flavours and Textures. Academic Press, New York.

Ganong, W.F. (2003). Buku Ajar Fisiologi Kedokteran. Edisi $K e-21$. Penterjemah Widjajakusumah, M.D. EGC Penerbit Buku Kedokteran, Jakarta.

Gharib, O.A. (2009). Effects of kombucha on oxidative stress induced nephrotoxicity in rats. Chinese Medicine 4: 2330 .

Guyton, A.C. (1995). Buku Ajar Fisiologi Kedokteran. Edisi $\mathrm{Ke}$-7. Penterjemah Tengadi, K.A. EGC Penerbit Buku Kedokteran, Jakarta.

Guyton, A.C. dan Hall, J.E. (1997). Buku Ajar Fisiologi Kedokteran. Edisi Ke-9. Penterjemah Setiawan, I. Tengadi, K.A. dan Santoso, A. EGC Penerbit Buku Kedokteran, Jakarta.

Hoffbrand, A.V., Petit, J.E. dan Moss, P.A.H. (2005). Hematologi. Edisi Ke-4. Penterjemah Mahanani D.A. EGC Penerbit Buku Kedokteran, Jakarta.

Jain, N.C. (1993). Essential of Veterinary Hematology. Lea and Febiger, Philadelphia.

Jayabalan, R., Marimuthu, S. dan Swaminathan, K. (2007). Changes in content of organic acids and tea polyphenols during kombucha tea fermentation. Food Chemistry 102: 392-398.

Kresno, S.B.(1988). Pengantar Hematologi dan Imunohematologi. Fakultas Kedokteran Universitas Indonesia, Jakarta.

Laurence, D.R. dan Bacharah, A.L. (1964). Evaluation of Drugs Activities. Academic Press, London and New York.

Lehninger, A.L. (1990). Dasar-dasar Biokimia Jilid I. Penterjemah Thenawidjaja, M. Erlangga, Jakarta.

Martini, F., Ober. W.C., Garsson C.W. dan Welch, K. (1992). Fundamentals of Anatomy Physiology. $12^{\text {th }} \mathrm{Ed}$. Prentic Hall. Englewood Clifts. New Jersey.

Maysaroh, L. (2010). Evaluasi Darah (Glukosa Darah, Hb, Leukosit, dan Nilai Hematokrit) Mencit Betina (Mus musculus L.) setelah Dicekok dengan Ekstrak Rimpang Rumput Teki (Cyperus rotundus L.). Skripsi. Fakultas Matematika dan Ilmu Pengetahuan Alam, Universitas Lampung, Bandar Lampung.
Meyer, D., Cole, J.E. dan Carroll, L.J. (1975). Veterinary Laboratory Medicine Interpretation and Diagnosis. W. B. Saunders Co. Philadelphia, London, Toronto, Montreal, Sydney, Tokyo.

Morton, J.F. (1999). Roselle Hibiscus sabdarifa L. http:// www.transgenica.com/database/h/hibiscus.htm. Januari 2011].

Murugesan, G.S., Sathishkumar, M., Jayabalan, R., Binupriya, A.R., Swaminathan, K. dan Yun, S.E. (2009). Hepatoprotective and curative properties of kombucha tea against carbon tetrachlorida-induced toxicity. Journal of Microbiology and Biotechnology 19(4): 397-402.

Naland, H. (2004). Kombucha Teh Ajaib. Pencegah dan Penyembuh Aneka Penyakit. Agromedia Pustaka, Jakarta.

Renova, R.N. (2005). Gambaran Sel Darah Putih Akibat Pemberian Kapsul Buah Mengkudu (Morinda citrifolia) pada Kelinci. Skripsi. Fakultas Kedokteran Hewan. Institut Pertanian Bogor, Bogor.

Ross, P., Meyer, R. dan Benziman, M. (1991). Cellulose biosynthesis and function in bacteria. Microbiology Reviews 55: 35-58.

Sabrina, N. (2005). Respon Eritrosit, Leukosit, Kadar Hemoglobin, dan Nilai Hematokrit Darah Kelinci yang Diberi Kapsul Buah Mengkudu (Morinda citrifolia). Skripsi. Fakultas Kedokteran Hewan. Institut Pertanian Bogor. Bogor.

Sundah, N.C. (2008). Pembuatan Serbuk Effervescent Rosella (Hibiscus sabdariffa L): Kajian Konsentrasi Maltodekstrin dan Suhu Pengeringan yang Berbeda terhadap Sifat Fisik, Kimia dan Organoleptik. Skripsi. Fakultas Teknologi Pertanian. Universitas Brawijaya, Malang.

Swenson, M.J. (1997). Duke's Physiology of Domestic Animal. $10^{\text {th }} \mathrm{Ed}$. Publishing Associates a Division of Cornell University, Ithaca and London.

Tzu, L.L., Hui, H.L, Chang, C.C., Ming, C.L., Ming C.C. dan Chau, J.W. (2007). Hibiscus sabdariffa extract reduces serum cholesterol in men and women. Nutrition Research 27: 140-145.

Xu, Y., Zhao, H., Zhang, M., Li, C.J., Lin, X.Z., Sheng J. dan Shi W. (2011). Variations of antioxidant properties and NO scavenging abilities during fermentation of tea. International Journal of Molecular Sciences 12: 4574 4590 . 